\title{
Factors associated with folic acid knowledge and intake among pregnant women in Sudan
}

Mohamed A. Alsammani ${ }^{1,2}$, Abdelillah Kunna ${ }^{2}$ and Elsheikh M. Adam ${ }^{3}$



ABSTRACT Preconceptual folic acid use is known to have a protective effect against neural tube defects (NTDs). This study assessed knowledge and determinants of awareness on folic acid use among pregnant women at Omdurman Maternity Hospital, Sudan during 2014. The standardized, anonymous questionnaire was used to collect data. Almost $80 \%$ of respondents had heard of folic acid. College-educated women (92.2\%) knew more about folic acid and used it more often in the pre-conceptual period (8.3\%). Doctors were the commonest source of information on folic acid (62\%). Fewer subjects (8.9\%) knew that it prevented birth defects, and 33.8\% of subjects knew that green leafy vegetables are a source of folic acid. Of all subjects, only $3.2 \%$ use it preconceptually. Supplementation of folic acid preconceptually needs to be addressed in order to reduce the rate of NTDs found in Sudan.

\section{Facteurs associés aux connaissances et déterminants concernant l'apport en acide folique parmi les femmes en âge de procréer au Soudan}

RÉSUMÉ La consommation d'acide folique avant la conception est connue pour avoir un effet protecteur contre les anomalies du tube neural (ATD). La présente étude avait pour objectif d'évaluer les connaissances et déterminants de la sensibilisation à la consommation d'acide folique parmi les femmes enceintes à la maternité de I'hôpital d'Omdourman au Soudan en 2014. Un questionnaire, standardisé et anonyme, a été utilisé pour collecter des données. Près de 80 \% des répondants avaient déjà entendu parler de l'acide folique. Les femmes ayant reçu une éducation universitaire (92,2 \%) en savaient plus sur l'acide folique et en consommaient davantage souvent durant la période préconceptionnelle (8,3\%). Les médecins étaient la source d’information la plus courante sur l'acide folique (62\%). Un nombre inférieur de sujets (8,9\%) étaient conscients que l'acide folique permet de prévenir les malformations congénitales et 33,8\% des sujets savaient que les légumes vert à feuilles constituent une source d'acide folique. Parmi tous les sujets, seulement 3,2 \% en consommaient avant la conception. La supplémentation préconceptionnelle en acide folique doit être prise en compte afin de réduire la forte incidence des ATD constatées au Soudan.

${ }^{7}$ Department of Obstetrics and Gynaecology, College of Medicine, Qassim University, Al-Mulida, Saudi Arabia (Correspondence to: Mohamed A. Alsammani:m_sammani@yahoo.com). ${ }^{2}$ Department of Obstetrics and Gynaecology, College of Medicine, University of Bahri, Khartoum, Sudan. ${ }^{3}$ Department of Obstetrics and Gynaecology, Omdurman Maternity Hospital, Omdurman, Sudan.

Received: 13/10/15; accepted: 15/01/17 


\section{Introduction}

Many studies have shown associations between neural tube defects and inadequate maternal intake of folic acid before or during pregnancy and that folic acid supplementation could reduce neural tube defects $(1-4)$. It has been recommended that during routine gynaecological visits women of reproductive age should be counselled to adjust their daily folic acid intake (5).

It has been reported that more than 300000 cases of neural tube defects occur worldwide each year, and many are in low-income countries (6). While the incidence of neural tube defects is falling in the United States of America (USA) and Western Europe, these congenital abnormalities remain a significant health problem in Africa (6).

In the United Kingdom, the birth prevalence of neural tube defects per 1000 births decreased by $93 \%$, from 3.6 in 1964 to 0.3 in 2004; this decline was due to the adequate intake of folic acid (7). A study in Omdurman Maternity Hospital, Sudan in 2003/2004reported an incidence of neural tube defects of 3.5 per 1000 deliveries (8). None of mothers of babies with neural tube defects or the control mothers had received preconception folate supplements. This high incidence of neural tube defects may indicates a lack of knowledge and adequate intake of folic acid among pregnant women in Omdurman Maternity Hospital. All women receiving antenatal care at Omdurman Maternity Hospital are advised to take folic acid tablets during pregnancy.

No previous study has been conducted among Sudanese women of reproductive age about their awareness and intake of folic acid. The aim of the present study therefore was to determine knowledge of folic acid and the determinants of folic acid use among pregnant women attending Omdurman Maternity Hospital.

\section{Study design}

This was a cross-sectional study conducted at Omdurman Maternity Hospital, Sudan from August 2014 to January 2015. The population of Omdurman city was 2395159 in 2008. Founded in 1957, Omdurman Maternity Hospital is the largest tertiary maternity hospital in Sudan with 25 000-30 000 births a year. In addition to the city population, the hospital serves a large non-urban area.

\section{Study sample and sample size}

The study sample was drawn from women who were visiting the antenatal clinics of Omdurman Maternity Hospital for routine antenatal care during the study period, August 2014 to January 2015. All women attending the antenatal clinic who were willing to participate were included in the study.

In estimating the prevalence of folic acid awareness, it was assumed that the results for Sudan would be similar to that of Nigeria at $64 \%$ (9). With an error rate of $2.5 \%$, a level of significance (type 1 error) of 1\%, and 99\% confidence interval (CI), a sample size of 1048 women was needed to achieve the objective of our study assuming $10 \%$ nonresponse.

\section{Data collection}

Data were collected using a questionnaire administered to each woman by a senior registrar in obstetrics and gynaecology. The questionnaire consisted of data on the knowledge and use of folic acid, sources of knowledge, period folic acid was taken, and knowledge of the potential benefits of taking folic acid supplements. In addition, selected sociodemographic and obstetric data were gathered: age, education, occupation, residence, parity, prior abortions, booking status (i.e. early 1st trimester antenatal visit with booking to deliver in the hospital), antenatal care use and trimester when antenatal care was started.

The questionnaire contained criteria for folic acid intake and knowledge related to trimester of pregnancy. Questions used to assess knowledge were whether respondents had ever heard about folic acid (yes/no) and whether they knew the appropriate time to take folic acid (preconception, first trimester, throughout pregnancy or never). Furthermore, participants were asked if they knew the beneficial effects of folic acid (protection against neural tube defects) and the sources of food containing folic acid (green vegetables). Preconception intake of folic acid is considered effective use based on WHO recommendations (10) and green vegetables were considered an appropriate source of folic acid

\section{Statistical analysis}

SPSS, version 15.0 was used to record and analyse the data. Descriptive analyses were used: proportions were compared between women who had heard of folic acid and those who had not. Bivariate and multivariable analyses were performed, one with awareness of folic acid as the dependent variable, and the other with preconception intake of folic acidas the dependent variable. The independent variables included in the analyses were: age $(<18,18-30,31-40$, $\geq 41$ years), residence (urban, rural), education (illiterate, primary, secondary, higher secondary, university and above), occupation (housewife, selfemployed business woman, employee, labourer), parity $(0,1-4, \geq 5)$, prior abortion (yes, no), antenatal care - at least one visit (yes/no), first entry into antenatal care (1st, 2nd, 3rd trimester) and booking status(booked, not booked). Adjusted odds ratios (OR) and $95 \%$ CIs were estimated. A P-value $<0.05$ was considered statistically significant. 


\section{Ethical considerations}

The study was approved by the ethics committees of the Sudanese specialization board and the Omdurman Maternity Hospital. Informed verbal consent to participate in the study was obtained from each women.

\section{Results}

A total of 1300 women were approached and 1150 aged $18-45$ years agreed to participate and were interviewed; of these, 1000 (86.9\%) women were included in the study, while 150 were excluded because of incomplete information (declined to give information).

Table 1 shows the characteristics of the women and their knowledge and intake of folic acid. Of the 1000 women included in the study, $813(81.3 \%)$ had heard of folic acid. Of those who had heard of folic acid, the highest proportion $(85.7 \%)$ was in the age group $<18$ years and the lowest was the 41 years and older age group (72.4\%). Awareness was highest among multiparous women (parity 1-4) (85.1\%) and women who had a university degree or higher $(88.8 \%)$. With regard to folic acid intake, few women $(<4 \%)$ took it during the preconception period but more women who had a university degree or higher used it in the first trimester $(66.3 \%)$ than less educated women. The majority of the women (91.2\%) had attended at least one antenatal care visit, $72.9 \%$ of whom were booked. The majority of the women $61.3 \%(n=613)$ had started their antenatal care in the first trimester.

Table 2 shows the participants' knowledge about folic acid. With regard to sources of information on the benefits of folic acid, $62 \%$ of the women got their information from doctors, followed by newspapers at $21 \%$; the least mentioned source of information was family members, $3 \%$. The greatest proportion of the women $(24.7 \%)$ stated that folic acid prevents anaemia; few women $(8.9 \%)$ knew that it prevents birth defects. In addition, only $3.8 \%$ of the women were aware that green leafy vegetables were rich in folic acid.

Table 3 show the multivariable logistic regression analysis of the factors associated with ever having heard about folic acid. The variables significantly associated with awareness of folic acid were living in urban areas $(\mathrm{OR}=2.17$, 95\% CI: 1.51-3.21, $P<0.001)$, and attending antenatal care $(\mathrm{OR}=2.2,95 \%$ CI: $1.27-3.96, P=0.005)$. Maternal age, occupation, parity, the time of starting antenatal care, prior abortion and being booked were not associated with folic acid awareness.

Multivariable logistic regression analysis of the association between sociodemographic and obstetric characteristics and preconception use of folic acid is shown in Table 4. Preconception use of folic acid was significantly associated with living in urban areas $(\mathrm{OR}=1.80$, 95\% CI: $1.35-2.40, P<0.001)$, past history of abortion $(\mathrm{OR}=1.42,95 \% \mathrm{CI}$ : 1.05-1.92, $P=0.022)$, being booked $(\mathrm{OR}=1.60,95 \% \mathrm{CI}: 1.16-2.25, P=$ $0.005)$ and first trimester enrollment in antenatal care $(\mathrm{OR}=1.70,95 \% \mathrm{CI}$ : $1.07-2.73, P=0.024)$.

\section{Discussion}

In the present study, about $80 \%$ of the women had heard about folic acid, but only $8.9 \%$ knew that folic acid prevents birth defects and 3.2\% used it during the preconception period, while $55.2 \%$ used it during the first trimester. Information about folic acid was mostly from physicians (62\%) and $33.8 \%$ of the participants knew that green leafy vegetables are rich in folic acid. A higher level of education, living in an urban area and attending antenatal care were significantly associated with awareness of folic acid. In addition, higher level of education, living in an urban area, first trimester enrollment in antenatal care and being booked were significantly associated with preconception use of folic acid.

The level of awareness of folic acid in the present study (80\%) is higher than that reported in Egypt (62.4\%) (11), Lebanon (60\%) (12) and Nigeria (37\%) (13), but lower than the prevalence reported from Jordon (93.4\%) (14) and Saudi Arabia (88.4\%) (15) (Table 5). In our study, a large proportion of the women aged $18-30$ years (82.9\%) had heard of folic acid, which is in agreement with previously published data (16). A possible reason for this awareness is that women in this age group are just starting their reproductive lives and may be more receptive to information compared with older mothers.

Almost half of all birth defects are of unknown causes. For neural tube defects, folate deficiency is considered the most important nutritional risk factor, and supplementation with preconception folic acid has been associated with a reduced risk of neural tube defects $(17,18)$. The World Health Organization recommends that all women when first trying to conceive should take a daily supplementation of $400 \mu \mathrm{g}$ of folic acid and continue until 12 weeks of gestation (19).According to our study, despite the high level of awareness of folic acid, only $3.2 \%$ of the women used it before conception, which is lower than in other Middle East countries including Lebanon (6.2\%) (12), Egypt (8.8\%) (11), Jordon (16.9\%) (14) and Israel (17.6\%) (1) (Table 5). This difference in preconception use can be explained by differences in educational levels between countries.

The most common source of information on folic acid in the present study was doctors $(62 \%)$, followed by newspapers $(21 \%)$; this result is in accordance with previously regional data $(11,12,14,18)$. However, the fact that most women knew about folic acid but so few used it before conception 


\begin{tabular}{|c|c|c|c|c|c|}
\hline \multirow[t]{3}{*}{ Characteristic } & \multirow{3}{*}{$\begin{array}{c}\text { Total }(n=1000) \\
\text { No. }(\%)\end{array}$} & \multirow{3}{*}{$\begin{array}{l}\text { Ever heard of } \\
\text { folic acid } \\
\text { No. (\%) }\end{array}$} & \multicolumn{3}{|c|}{ Time of folic acid intake } \\
\hline & & & $\begin{array}{l}\text { Any time after } \\
\text { first trimester }\end{array}$ & Preconception & First trimester \\
\hline & & & No. (\%) & No. (\%) & No. (\%) \\
\hline \multicolumn{6}{|l|}{ Age (years) } \\
\hline$<18$ & $14(1.4)$ & $12(85.7)$ & $3(21.4)$ & $1(7.1)$ & $7(50.0)$ \\
\hline $18-$ & $636(63.6)$ & 527 (82.9) & $130(20.4)$ & $23(3.6)$ & $361(56.8)$ \\
\hline $31-$ & $292(29.2)$ & $232(79.5)$ & $69(23.6)$ & $8(2.7)$ & $152(52.1)$ \\
\hline$\geq 41$ & $58(5.8)$ & $42(72.4)$ & $12(20.7)$ & $0(0)$ & $27(46.6)$ \\
\hline \multicolumn{6}{|l|}{ Residence } \\
\hline Urban & $628(62.8)$ & $539(85.8)$ & $123(19.6)$ & $21(3.3)$ & $385(61.3)$ \\
\hline Rural & $372(37.2)$ & $274(73.7)$ & $93(25.0)$ & $11(3.0)$ & 167 (44.9) \\
\hline \multicolumn{6}{|l|}{ Education } \\
\hline Illiterate & 209 (20.9) & $163(78.0)$ & $41(19.6)$ & $3(1.4)$ & $112(53.6)$ \\
\hline Primary & $258(25.8)$ & $197(76.4)$ & $52(20.2)$ & $10(3.9)$ & $134(51.9)$ \\
\hline Secondary & $284(28.4)$ & $239(84.2)$ & $66(23.2)$ & $9(3.2)$ & $158(55.6)$ \\
\hline Higher secondary & $160(16.0)$ & $135(84.4)$ & $41(25.6)$ & $7(4.4)$ & $86(53.8)$ \\
\hline University and above & $89(8.9)$ & $79(88.8)$ & $16(18.0)$ & $3(3.4)$ & $59(66.3)$ \\
\hline \multicolumn{6}{|l|}{ Occupation } \\
\hline Housewife & $874(87.4)$ & $700(80.1)$ & $201(23.0)$ & $15(1.7)$ & 475 (54.3) \\
\hline Employee & $81(8.1)$ & $75(92.6)$ & $7(8.6)$ & $17(21.0)$ & $51(63.0)$ \\
\hline Labourer & $35(3.5)$ & $29(82.9)$ & $6(17.1)$ & $0(0)$ & $19(54.3)$ \\
\hline $\begin{array}{l}\text { Self-employed business } \\
\text { woman }\end{array}$ & $10(1.0)$ & $9(90.0)$ & $2(20.0)$ & $0(0)$ & $7(70.0)$ \\
\hline \multicolumn{6}{|l|}{ Parity } \\
\hline 0 & $666(66.6)$ & $545(81.8)$ & 139 (20.9) & $25(3.8)$ & $378(56.8)$ \\
\hline $1-$ & $175(17.5)$ & $149(85.1)$ & 33 (18.9) & $4(2.3)$ & $104(59.4)$ \\
\hline$\geq 5$ & $159(15.9)$ & $119(74.8$ & $44(27.7)$ & $3(1.9)$ & $70(44.0)$ \\
\hline \multicolumn{6}{|l|}{ Prior abortion } \\
\hline Yes & $271(27.1)$ & $221(81.5)$ & $65(24.0)$ & $3(1.1)$ & $137(50.6)$ \\
\hline No & $729(72.9)$ & $592(81.2)$ & $151(20.7)$ & $29(4.0)$ & $409(56.1)$ \\
\hline \multicolumn{6}{|c|}{ Antenatal care (at least one visit) } \\
\hline Yes & $912(91.2)$ & $754(82.7)$ & $201(22.0)$ & $31(3.4)$ & $513(56.3)$ \\
\hline No & $88(8.8)$ & $59(67.0)$ & $15(17.0)$ & $1(1.1)$ & $39(44.3)$ \\
\hline \multicolumn{6}{|l|}{ Antenatal care entry } \\
\hline 1st trimester & $613(61.3)$ & $534(81.7)$ & 105 (17.1) & $24(3.9)$ & $386(63.0)$ \\
\hline 2nd trimester & $192(19.2)$ & $138(71.9)$ & $62(32.3)$ & $3(1.6)$ & $71(37.0)$ \\
\hline 3rd trimester & $92(9.2)$ & $64(69.2)$ & $23(25.0)$ & $2(2.2)$ & $37(40.2)$ \\
\hline \multicolumn{6}{|l|}{ Booking } \\
\hline Booked & $742(74.2)$ & 615 (82.9) & $158(21.3)$ & $24(3.2)$ & $430(58.0)$ \\
\hline Not booked & $258(25.8)$ & $198(76.7)$ & $58(22.5)$ & $8(3.1)$ & $106(41.1)$ \\
\hline
\end{tabular}

indicates that there is a real need for a regional campaign to motivate women to take folic acid supplements as recommended. Furthermore, folic acid intake can be improved by administration of folic acid during premarital health evaluation for genetic abnormalities and serology screening as done in China, and by educating couples about the role of folic acid in preventing neural tube defects. In China, premarital health examination increased adequate use by $20 \%(20)$.The United States Food and Drug Administration started the policy of folic acid fortification of grain 
products to increase the intake of women during their reproductive years by a daily dose of $100 \mu \mathrm{g}$ (21). This policy resulted in a decline in the prevalence of spina bifida by $31 \%$ and neural tube defects by $6 \%(22)$.

Of the women surveyed, only $8.9 \%$ knew that folic acid prevents birth defects. This percentage is comparable to the rate in Qatar (8.7\%) (23), but lower than rates in Saudi Arabia (15) and the United Arab Emirates (24), 11.2\% and $14 \%$ respectively. In our study, lack of knowledge and less preconception use of folic acid may explain the high rate of neural tube defects prevalence $(12.5 / 10$ 000 births) in our setting (25),compared with rates of $2 / 10000,3.3 / 10$ 000, and 0.4/10 000 births reported from Egypt, Nigeria and Saudi Arabia respectively (25).

The present study demonstrated the association between awareness of folic acid and living in urban areas, higherlevel of education and antenatal care attendance. This finding is consistent with previous studies which concluded that women with higher education knew more about folic acid and were more likely to use it $(2,20)$. Women living in rural areas and having a lower education level knew less about folic acid and were less likely to use it (9). Also, our study showed a significant association between preconception use of folic acid and living in urban areas, being booked, a higher level of education and antenatal care attendance. On the other hand, some studies failed to demonstrate any association between sociodemographic characteristics and folic acid use (25).

As our study was in only one hospital in Sudan rather than a multicentre study, our sample may not be representative of the population so the results cannot be generalized to wider population. Further studies in other parts of Sudan would be useful to provide

\begin{tabular}{|c|c|}
\hline Knowledge question ${ }^{\mathrm{a}}$ & No. (\%) \\
\hline \multicolumn{2}{|l|}{ Sources of information on folic acid } \\
\hline Doctor & $620(62.0)$ \\
\hline Newspaper & $210(21.0)$ \\
\hline Nurse & $121(12.1)$ \\
\hline Pharmacist & $150(15.0)$ \\
\hline Family member & $30(3.0)$ \\
\hline Television & $118(11.8)$ \\
\hline \multicolumn{2}{|c|}{ Effect offolic acid intake before and during pregnancy } \\
\hline Prevents birth defects & $89(8.9)$ \\
\hline Good for body & $77(7.7)$ \\
\hline Prevents anaemia & $247(24.7)$ \\
\hline Good for bones & $76(7.6)$ \\
\hline Helps growth and development & $102(10.2)$ \\
\hline Good for pregnant women & $71(7.1)$ \\
\hline Not sure & $89(8.9)$ \\
\hline Pre-conception use & $32(3.2)$ \\
\hline \multicolumn{2}{|l|}{ Foods rich in folic acid } \\
\hline Green leafy vegetables & $338(33.8)$ \\
\hline Fish & $174(17.4)$ \\
\hline Fruits & $250(25.0)$ \\
\hline Liver & $206(20.6)$ \\
\hline Milk & $372(37.2)$ \\
\hline Do not know & $284(28.4)$ \\
\hline \multicolumn{2}{|l|}{ Type of vitamin tablets taken } \\
\hline Folic acid & $192(19.2)$ \\
\hline Iron & 163 (16.3) \\
\hline Multivitamins & $134(13.4)$ \\
\hline Calcium & $61(6.1)$ \\
\hline None & $450(45.0)$ \\
\hline
\end{tabular}

${ }^{a}$ Multiple responses were permitted (percentages do not add to $100 \%$ ).

information on folic acid use for the whole country.

\section{Conclusion}

Our study has shown that the preconception use of folic acid among women in Omdurman is inadequate. Women who had higher education, lived in urban areas, were booked, and had attended antenatal care knew more about preconception use of folic acid and used it significantly more. Doctors were the main source of information on folic acid.

Given the low rates of use of folic acid found in our study and the high prevalence of neural tube defects in Sudan, programmes to promote folic acid use and supplementation with folic acid at the time of premarital examination until the end of the first trimester are warranted.

\section{Funding: None.}

Competing interests: None declared. 


\begin{tabular}{|c|c|c|c|c|}
\hline \multirow[t]{2}{*}{ Variable } & \multicolumn{2}{|c|}{ Bivariate analysis } & \multicolumn{2}{|c|}{ Multivariable analysis } \\
\hline & OR $(95 \% \mathrm{CI})$ & $P$-value & OR $(95 \% \mathrm{Cl})$ & $P$-value \\
\hline \multicolumn{5}{|l|}{ Age (years) } \\
\hline \multicolumn{5}{|l|}{$<18^{\mathrm{a}}$} \\
\hline $18-$ & $1.24(0.27-5.62)$ & 0.779 & $0.45(0.08-2.44)$ & 0.35 \\
\hline $31-$ & $1.55(0.34-7.12)$ & 0.572 & $0.85(0.41-1.77)$ & 0.66 \\
\hline$\geq 41$ & $2.29(0.46-11.36)$ & 0.312 & $0.97(0.47-1.99)$ & 0.93 \\
\hline \multicolumn{5}{|l|}{ Residence } \\
\hline \multicolumn{5}{|l|}{ Rural $^{\mathrm{a}}$} \\
\hline Urban & $2.17(1.57-2.99)$ & $<0.001$ & $2.17(1.51-3.21)$ & $<0.001$ \\
\hline \multicolumn{5}{|l|}{ Education } \\
\hline \multicolumn{5}{|l|}{ Illiterate ${ }^{a}$} \\
\hline Primary & $1.097(0.71-1.7)$ & 0.676 & $1.9(0.89-4.08)$ & 0.096 \\
\hline Secondary & $0.667(0.42-1.05)$ & 0.082 & $1.8(0.87-3.84)$ & 0.113 \\
\hline Higher secondary & $0.656(0.38-1.12)$ & 0.125 & $1.1(0.54-2.44)$ & 0.725 \\
\hline University and above & $0.45(0.22-0.94)$ & 0.032 & $1.1(0.49-2.48)$ & 0.806 \\
\hline \multicolumn{5}{|l|}{ Occupation } \\
\hline \multicolumn{5}{|l|}{ Employee $^{a}$} \\
\hline Housewife & $0.32(0.14-0.75)$ & 0.009 & $1.61(0.20-13.22)$ & 0.660 \\
\hline Labourer & $0.83(0.34-2.04)$ & 0.688 & $0.71(0.07-6.85)$ & 0.768 \\
\hline Self-employed business woman & $0.45(0.06-0.55)$ & 0.446 & $1.23(0.12-12.40)$ & 0.862 \\
\hline \multicolumn{5}{|l|}{ Parity } \\
\hline \multicolumn{5}{|l|}{$1^{\mathrm{a}}$} \\
\hline $1-$ & $0.79(0.50-1.25)$ & 0.306 & $0.88(0.53-1.45)$ & 0.609 \\
\hline$\geq 5$ & $1.51(1.01-2.28)$ & 0.047 & $0.63(0.34-1.17)$ & 0.142 \\
\hline \multicolumn{5}{|l|}{ Prior abortion } \\
\hline \multicolumn{5}{|l|}{ Yes $^{\mathrm{a}}$} \\
\hline No & $1.02(0.71-1.46)$ & 0.902 & $1.01(0.69-0.49)$ & 0.951 \\
\hline \multicolumn{5}{|l|}{ Antenatal care (at least one visit) } \\
\hline \multicolumn{5}{|l|}{$\mathrm{No}^{\mathrm{a}}$} \\
\hline Yes & $2.30(1.46-3.78)$ & $<0.001$ & $2.20(1.27-3.96)$ & 0.005 \\
\hline \multicolumn{5}{|l|}{ Antenatal care entry } \\
\hline \multicolumn{5}{|l|}{ Not used ${ }^{a}$} \\
\hline 1sttrimester & $0.44(0.27-0.73)$ & 0.001 & $0.58(33-1.02)$ & 0.059 \\
\hline 2nd trimester & $1.16(0.67-2.00)$ & 0.596 & $1.35(0.73-2.49)$ & 0.341 \\
\hline 3rd trimester & $1.32(0.70-2.47)$ & 0.392 & $1.75(0.88-3.48)$ & 0.114 \\
\hline \multicolumn{5}{|l|}{ Booked } \\
\hline \multicolumn{5}{|l|}{$Y_{e s}{ }^{a}$} \\
\hline No & $1.50(1.04-2.08)$ & 0.030 & $0.85(0.56-1.29)$ & 0.449 \\
\hline
\end{tabular}

${ }^{a}$ Reference category.

$O R=$ odd ratios; $C I=$ confidence interval. 


\begin{tabular}{|c|c|c|c|c|}
\hline \multirow[t]{2}{*}{ Variable } & \multicolumn{2}{|c|}{ Bivariate analysis } & \multicolumn{2}{|c|}{ Multivariable analysis } \\
\hline & OR $(95 \% \mathrm{Cl})$ & $P$-value & OR(95\%Cl) & $P$-value \\
\hline \multicolumn{5}{|l|}{ Age (years) } \\
\hline \multicolumn{5}{|l|}{$<18^{\mathrm{a}}$} \\
\hline $18-$ & $1.7(0.57-4.88)$ & 0.345 & $0.84(0.23-3.07)$ & 0.789 \\
\hline $31-$ & $1.4(0.47-4.1)$ & 0.552 & $0.87(0.46-1.65)$ & 0.676 \\
\hline$\geq 41$ & $1.0(0.31-3.29)$ & 0.987 & $0.88(0.47-1.67)$ & 0.706 \\
\hline \multicolumn{5}{|l|}{ Residence } \\
\hline \multicolumn{5}{|l|}{ Rural $^{\mathrm{a}}$} \\
\hline Urban & $2.1(1.58-2.67)$ & $<0.001$ & $1.80(1.35-2.40)$ & $<0.001$ \\
\hline \multicolumn{5}{|l|}{ Education } \\
\hline \multicolumn{5}{|l|}{ Illiterate ${ }^{a}$} \\
\hline Primary & $0.91(0.63-1.32)$ & 0.630 & $1.02(0.69-1.51)$ & 0.917 \\
\hline Secondary & $1.02(0.71-1.46)$ & 0.906 & $1.04(0.71-1.52)$ & 0.842 \\
\hline Higher secondary & $0.95(0.63-1.43)$ & 0.792 & $0.99(0.64-1.54)$ & 0.967 \\
\hline University and above & $1.96(1.162-3.30)$ & 0.012 & $1.70(0.98-2.97)$ & 0.059 \\
\hline \multicolumn{5}{|l|}{ Occupation } \\
\hline \multicolumn{5}{|l|}{ Employee $^{\mathrm{a}}$} \\
\hline Housewife & $0.96(0.49-1.88)$ & 0.899 & $1.15(0.21-6.34)$ & 0.194 \\
\hline Self-employed business woman & $2.10(0.54-8.21)$ & 0.282 & $1.10(0.55-2.18)$ & 0.747 \\
\hline Labourer & $1.10(0.91-2.33)$ & 0.114 & $0.55(0.11-2.70)$ & 0.462 \\
\hline \multicolumn{5}{|l|}{ Parity } \\
\hline \multicolumn{5}{|l|}{$0^{\mathrm{a}}$} \\
\hline $1-$ & $1.12(0.80-1.58)$ & 0.495 & $1.23(0.85-1.76)$ & 0.27 \\
\hline$\geq 5$ & $0.523(0.37-0.75)$ & $<0.001$ & $0.67(0.45-1.05)$ & 0.08 \\
\hline \multicolumn{5}{|l|}{ Prior abortion } \\
\hline \multicolumn{5}{|l|}{$Y_{e s}{ }^{a}$} \\
\hline No & $0.76(0.57-1.00)$ & 0.051 & $1.42(1.05-1.92)$ & 0.022 \\
\hline \multicolumn{5}{|l|}{ Antenatal care (at least one visit) } \\
\hline \multicolumn{5}{|l|}{$\mathrm{No}^{\mathrm{a}}$} \\
\hline Yes & $1.90(1.23-3.02)$ & 0.004 & $1.45(0.87-2.4)$ & 0.154 \\
\hline \multicolumn{5}{|l|}{ Antenatal care entry } \\
\hline \multicolumn{5}{|l|}{ Not used $^{\mathrm{a}}$} \\
\hline 1st trimester & $1.80(1.18-2.73)$ & 0.006 & $1.70(1.07-2.73)$ & 0.024 \\
\hline 2nd trimester & $0.66(0.40-1.07)$ & 0.091 & $0.70(0.41-1.20)$ & 0.194 \\
\hline 3rd trimester & $0.98(0.56-1.73)$ & 0.950 & $0.90(0.49-1.66)$ & 0.747 \\
\hline \multicolumn{5}{|l|}{ Booking } \\
\hline \multicolumn{5}{|l|}{$\mathrm{No}^{\mathrm{a}}$} \\
\hline Yes & $2.20(1.67-2.98)$ & $<0.001$ & $1.60(1.16-2.25)$ & 0.005 \\
\hline
\end{tabular}

${ }^{a}$ Reference category.

$O R=$ odds ratio $; C I=$ confidence interval. 


\begin{tabular}{|c|c|c|c|c|c|}
\hline County (reference) & Year & Sample size & City & $\begin{array}{l}\text { Awareness of } \\
\text { folic acid (\%) }\end{array}$ & $\begin{array}{c}\text { Pre-conception } \\
\text { use (\%) }\end{array}$ \\
\hline Sudan (present study) & 2015 & 1000 & Omdurman & 80.0 & 3.2 \\
\hline Egypt (10) & 2102 & 660 & Cairo & 62.4 & 8.8 \\
\hline Jordon (14) & 2014 & 1000 & Amman & 93.4 & 16.9 \\
\hline Lebanon(12) & 2012 & 600 & Lebanon & 60.0 & 6.2 \\
\hline Israel (1) & 2008 & 1860 & Israel & 90.3 & 17.6 \\
\hline Qatar (19) & 2006 & 1800 & All Qatar & 53.7 & - \\
\hline Saudi Arabia (13) & 2012 & 1000 & Qassim & 88.4 & 4.4 \\
\hline Nigeria (11) & 2014 & 602 & Ibadan & 37.0 & 2.5 \\
\hline
\end{tabular}

\section{References}

1. Amitai $Y$, Fisher $N$, Haringman $M$, Meiraz H, Baram N, Leventhal A. Increased awareness, knowledge and utilization of preconceptional folic acid in Israel following a national campaign. Prev Med. 2004 Oct;39(4):731-7. PMID:15351539

2. Abdulrazzaq YM, Al-Gazali LI, Bener A, Hossein M, Verghese M, Dawodu A, et al. Folic acid awareness and intake survey in the United Arab Emirates. Reprod Toxicol. 2003 MarApr;17(2):171-6. PMID:12642149

3. de Walle HE, de Jong-van den Berg LT. Insufficient folic acid intake in the Netherlands: what about the future? Teratology. 2002 Jul;66(1):40-3. PMID:12115779

4. Group MVSR; MRC Vitamin Study Research Group. Prevention of neural tube defects: results of the Medical Research Council Vitamin Study. Lancet. 1991 Jul 20;338(8760):131-7. PMID:1677062

5. Cleves MA, Hobbs CA, Collins HB, Andrews N, Smith LN, Robbins JM. Folic acid use by women receiving routine gynecologic care. Obstet Gynecol. 2004 Apr;103(4):746-53. PMID:15051568

6. Fonseca EB, Raskin S, Zugaib M. Folic acid for the prevention of neural tube defects. Rev Bras Ginecol Obstet. 2013 Jul;35(7):287-9. PMID:24080839

7. Morris JK, Wald NJ. Prevalence of neural tube defect pregnancies in England and Wales from 1964 to 2004. J Med Screen. 2007;14(2):55-9. PMID:17626701

8. Elsheikh G, Ibrahim SA, Mahgoub F, Thorne J, Lewis M. Deliveries of babies with neural tube defects in Omdurman, Sudan. Cerebrospinal Fluid Res. 2004;1(1):1. PMID:15679934

9. Anzaku AS. Assessing folic acid awareness and its usage for the prevention of neural tube defects among pregnant women in Jos, Nigeria. J Basic Clin Reprod Sci. 2013;2(1):13-7.

10. World Health Organization, Department of Nutrition for Health and Development, Evidence and Programme Guidance Unit. Periconceptional daily folic acid (400 $\mu \mathrm{g})$ supplementation for prevention of neural tube defects. (www.who. int/selection_medicines/committees/expert/20/applications/Folic_acid.pdf?ua=1, accessed 2 October 2017).

11. Al-Darzi W, Al-Mudares F, Farah A, Ali A, Marzouk D. Knowledge of periconceptional folic acid use among pregnant women at Ain Shams University Hospital, Cairo, Egypt. East Mediterr Health J. 201410 12;20(9):561-8. PMID:25343469

12. Nasr Hage C, Jalloul M, Sabbah M, Adib SM. Awareness and intake of folic acid for the prevention of neural tube defects among Lebanese women of childbearing age. Matern Child Health J. 2012 Jan;16(1):258-65. PMID:21210201

13. LawalTA1, Adeleye AO. Determinants of folic acid intake during preconception and in early pregnancy by mothers in Ibadan, Nigeria. Pan Afr Med J. 2014 Oct 1;19:113. PMID:25722786
14. Alebous HD, Ma'aita ME, Alkhazaleh FA. Folic acid and neural tube defects: are Jordanian pregnant women aware? Clin Exp Obstet Gynecol. 2014;41(6):647-53. PMID:25551956

15. Al-Akhfash AA, Abdulla AM, Osman AM, Abdulgafar J, Almesned AA. Maternal knowledge and use of folic acid among Saudi females. Saudi Med J. 2013 Nov;34(11):1173-8. PMID:24252897

16. Wu DY, Brat G, Milla G, Kim J. Knowledge and use of folic acid for prevention of birth defects amongst Honduran women. Reprod Toxicol. 2007 Jun;23(4):600-6. Epub2007Feb12. PMID:17398068

17. Wolff T, Witkop CT, Miller T, Syed SB; U.S. Preventive Services Task Force. Folic acid supplementation for the prevention of neural tube defects: an update of the evidence for the U.S. Preventive Services Task Force. Ann Intern Med. 2009 May 5;150(9):632-9. PMID:19414843

18. Fernández-Gaxiola AC, De-Regil LM. Intermittent iron supplementation for reducing anaemia and its associated impairments in menstruating women. Cochrane Database Syst Rev. 201112 7; (12):CD009218. PMID:22161448

19. World Health Organization. Standards for maternal and neonatal care. Prevention of neural tube defects. 2007 (www. who.int/reproductivehealth/publications/maternal_perinatal_health/neural_tube_defects.pdf?ua=1, accessed 2 June 2017).

20. Ren A, Zhang L, Li Z, Hao L, Tian Y, Li Z. Awareness and use of folic acid, and blood folate concentrations among pregnant women in northern China-an area with a high prevalence of neural tube defects. Reprod Toxicol. 2006 Oct;22(3):431-6. PMID:16549319

21. Erickson JD. Folic acid and prevention of spina bifida and anencephaly. 10 years after the U.S. Public Health Service recommendation. MMWR Recomm Rep. 2002 Sep 13;51 RR-13:1-3. PMID:12353506

22. Williams LJ, Mai CT, Edmonds LD, Shaw GM, Kirby RS, Hobbs $\mathrm{CA}$, et al. Prevalence of spina bifida and anencephaly during the transition to mandatory folic acid fortification in the United States. Teratology. 2002 Jul;66(1):33-9. PMID:12115778

23. Bener A, Al Maadid MG, Al-Bast DA, Al-Marri S. Maternal knowledge, attitude and practice on folic acid intake among Arabian Qatari women. Reprod Toxicol. 2006 Jan;21(1):21-5. PMID:16112540

24. Kari JA, Bardisi ES, Baitalmal RM, Ageely GA. Folic acid awareness among female college students: neural tube defects prevention. Saudi Med J. 2008 Dec;29(12):1749-51. PMID:19082226

25. Zaganjor I, Sekkarie A, Tsang BL, Williams J, Razzaghi H, Mulinare J, et al. Describing the prevalence of neural tube defects worldwide: a systematic literature review. PLoS One. $2016 \mathrm{Apr}$ 11;11(4):e0151586. PMID: 27064786 